\title{
Erratum to: Production of chitin and bioactive materials from Black tiger shrimp (Penaeus monodon) shell waste by the treatment of bacterial protease cocktail
}

\author{
Tanmay Paul · Suman K. Halder · Arpan Das · Kuntal Ghosh • Arpita Mandal · \\ Pijush Payra • Prasenjit Barman • Pradeep K. Das Mohapatra • Bikas Ranjan Pati • \\ Keshab C. Mondal
}

Published online: 26 September 2014

(C) The Author(s) 2014. This article is published with open access at Springerlink.com

\section{Erratum to: 3 Biotech}

DOI 10.1007/s13205-014-0245-6

In the original publication of the article, the spelling of the first author name "Tanmay Paul" was incorrectly published as "Tanamy Paul". The correct author name is "Tanmay Paul".
Open Access This article is distributed under the terms of the Creative Commons Attribution License which permits any use, distribution, and reproduction in any medium, provided the original author(s) and the source are credited.

The online version of the original article can be found under doi:10.1007/s13205-014-0245-6.

T. Paul · S. K. Halder · A. Das · K. Ghosh · A. Mandal ·

P. Barman · P. K. Das Mohapatra - B. R. Pati .

K. C. Mondal ( $\square)$

Department of Microbiology, Vidyasagar University,

Midnapore 721102, West Bengal, India

e-mail: mondalkc@gmail.com

P. Payra

Department of Aquaculture Management and Technology,

Vidyasagar University, Midnapore 721102, West Bengal, India 